\title{
Science and Ethics
}

\section{La science et l'éthique}


Two speakers listed in the Symposium program are not represented in this volume. Dr. Guy Ourisson and Dr. Peter Singer did not submit manuscripts of their presentations.

Deux des intervenants listés dans le programme du colloque ne sont pas représentés dans cet ouvrage. Monsieur Guy Ourisson et Monsieur Peter Singer n'ont pas soumis de versions manuscrites de leurs allocutions. 


\section{Science and Ethics}

Proceedings of a symposium held in November 2000 under the auspices of The Royal Society of Canada

\section{La science et l'éthique}

Actes d'un colloque tenu en novembre 2000 sous les auspices de la Société royale du Canada

\section{Organized by / organisé par Howard Alper, OC, FRSC}

\section{Edited by / sous la direction de Patricia Demers, FRSC}

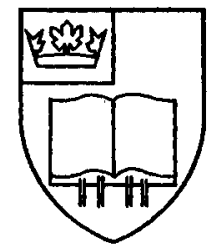

Transactions of The Royal Society of Canada Series VI, Volume XI, 2000

Mémoires de la Société royale du Canada Sixième série, Tome XI, 2000

Published for The Royal Society of Canada by

University of Toronto Press

Toronto Buffalo London 
(C) University of Toronto Press Incorporated 2001

Toronto Buffalo London

Printed in Canada

ISBN 0-8020-8476-1

\section{National Library of Canada Cataloguing in Publication Data}

CIP data is available from the National Library of Canada.

The opinions expressed in this publication are those of the authors and do not necessarily represent those of the Royal Society of Canada.

Les opinions qui sont exprimées dans cette publication sont celles des auteurs et ne reflètent pas nécessairement celles de la Société royale du Canada.

University of Toronto Press acknowledges the assistance to its publishing program of the Canada Council and the Ontario Arts Council.

We also acknowledge the financial support of the Government of Canada through the Book Publishing Industry Development Program (BPIDP) for our publishing activities. 